Diatom Research

2018, Volume 33, Issue 1, Pages 13-24

http://dx.doi.org/10.1080/0269249X.2018.1468359

http://archimer.ifremer.fr/doc/00441/55235/

(C) 2018 The International Society for Diatom Research

\title{
Description and phylogenetic position of Plagiolemma distortum sp. nov., a new raphid diatom (Bacillariophyceae) from French coastal waters
}

\author{
Nézan Elisabeth ${ }^{1,{ }^{*}}$, Bilien Gwenael ${ }^{1}$, Boulben Sylviane ${ }^{1}$, Mertens Kenneth ${ }^{1}$, Chomérat Nicolas ${ }^{1}$ \\ ${ }^{1}$ Ifremer, ODE/UL/LER BO, Station de Biologie Marine de Concarneau, Place de la Croix, 29900 \\ Concarneau, France \\ * Corresponding author : Elisabeth Nézan, email address : elisabeth.nezan@ifremer.fr
}

\begin{abstract}
:
A new marine raphid diatom, Plagiolemma distortum Nézan, sp. nov. is described from plankton samples from the Atlantic Ocean, south Brittany (north-western France), where it was regularly observed, but never in high abundances. Cells have an unusual and complex shape under light microscopy (LM) depending on their position and orientation. The two valves are highly vaulted and narrow in width (transapical axis). Cells contain four complexly lobed plastids and a variable number of refractive granules without particular localization. In addition, capsules containing motile cells were observed. Ultrastructural details of the frustules were investigated using scanning electron microscopy (SEM). The girdle bands are simple. Each valve possesses a sigmoid raphe raised on a ridge and ending in external large openings with elaborate internal helictoglossae. Moreover, each valve displays outer slit-like foramina and inner rounded hymenes, external terminal minute holes (micropyles) arranged in a row at the poles. In addition, on each valve face, one to several short transverse median costae are observed, terminating far away from the valve edges. Morphological comparisons with closely related taxa show that $P$. distortum is a new species. A video clip of a moving cell is provided for better understanding of the cell shape. The formation and function of capsules are discussed as well as the species habitat. A phylogenetic study, based on nuclear small subunit (SSU) ribosomal DNA (rDNA) sequence data, which includes new sequences relative to Plagiolemma and Plagiotropis, was performed. Furthermore, some morphological details observed with SEM are included in an emended generic diagnosis of Plagiolemma.
\end{abstract}

Keywords : capsules, habitat, molecular phylogeny, plastids, raphid diatom, video 


\section{Introduction}

Raphe-bearing pennate diatoms (raphid diatoms) display a large specific diversity, taxonomically arranged by Round et al.(1990) in eleven orders, thirty seven families and more than one hundred genera. This classification was based on valve morphology and ultrastructure. However, results of molecular phylogenetics have led to revisions of this system with the erection of new genera or reinstatement of old genera (Stepanek \& Kociolek 2014, 2016, Cox 2015). The genus Plagiolemma Paddock was erected to accommodate two species initially assigned to Tropidoneis Cleve, which is currently regarded as a synonym of Plagiotropis Pfitzer (Paddock 1988). Plagiolemma has not been studied by a combined morphological-molecular phylogenetic analysis. The two species belonging to this genus were Plagiolemma inflatum Paddock the generitype, originally described as Tropidoneis sp. (Simonsen 1974, pl. 29, figs. 1(a-b) and listed as Tropidoneis inflata in an unpublished manuscript by Hustedt, and Plagiolemma confusum (Hendey) Paddock, described as Tropidoneis confusa Hendey (1964, pl. 37, fig. 15). Paddock (1988) questioned the identification of a specimen from Tregaron, Cornwall, U.K., identified as T. confusa by Hendey (Paddock \& Sims 1981, pl. 12, fig. 92, Paddock 1988, pl. 27, figs 3-4). Plagiolemma inflatum was recorded from the Indian Ocean by Simonsen (1974) and from Singapore Harbour by Hustedt (Paddock 1988), while P. confusum was first observed from West Africa, and subsequently from the English Channel, East Africa and Kuwait (Hendey 1964, Foged 1975, Paddock 1988, Al-Yamani \& Saburova 2011). Both species were considered planktonic although $P$. confusum was also observed in sediments (Paddock 1988, Al-Yamani \& Saburova 2011).

Since December 2014, a marine raphid diatom species has been observed in plankton samples from French coasts of the Atlantic Ocean and the English Channel. This species was never abundant but the conspicuous appearance of its cells, living free or inside capsules, sparked our curiosity. This paper describes a new species of Plagiolemma, Plagiolemma distortum, through a detailed morphological study including both light microscopy (LM) and scanning electron microscopy (SEM). The habitat of $P$. distortum sp. nov. is discussed as well as the formation and function of capsules. In addition, the phylogenetic position of $P$. distortum sp. nov. is presented and leads to maintain rather than reject the family Plagiotropidaceae D.G. Mann. The generic diagnosis of Plagiolemma is also emended. 


\section{Materials and methods}

A total of twenty four plankton samples were collected between December 2014 and February 2016 with a vertical net tow ( $20 \mu \mathrm{m}$ mesh size) or a Niskin bottle at five sites in southern coastal Brittany, France: Ouessant Island $\left(48^{\circ} 27^{\prime} \mathrm{N}, 5^{\circ} 07^{\prime} \mathrm{W}\right)$, Lanveoc Bay ( $48^{\circ} 18^{\prime} \mathrm{N}, 4^{\circ} 27^{\prime}$ W), Kervel Bay $\left(48^{\circ} 06^{\prime} \mathrm{N}, 4^{\circ} 18^{\prime} \mathrm{W}\right)$, Concarneau Bay $\left(47^{\circ} 50^{\prime} \mathrm{N}, 3^{\circ} 57^{\prime} \mathrm{W}\right)$, and Penfret Island (47 $\left.43^{\prime} \mathrm{N}, 3^{\circ} 57^{\prime} \mathrm{W}\right)$ (Fig. 1). Temperature and salinity were measured in situ, using a conductimeter (Cond 3210) equipped with a standard conductivity cell, TetraCon 325 (WTW, Weilheim, Germany). Samples were preserved without fixation for immediate observation or culturing, or fixed with acidic Lugol's Iodine solution ( $0.1 \%$ final concentration) (Andersen $\&$ Throndsen 2003) and stored at $4^{\circ} \mathrm{C}$ until examination. In addition, another site more to the south of the study area was sampled with the aim of obtaining new genetic sequences of Plagiotropis, currently not available in GenBank, but useful for our phylogenetic analysis.

This site was the Meyran lagoon $\left(44^{\circ} 38^{\prime} \mathrm{N}, 1^{\circ} 07^{\prime} \mathrm{W}\right)$ where a water sample was obtained and fixed as above.

For cultivation, two unfixed samples from Ouessant Island collected in April 2015, when sea surface water temperature (SST) was $11.2^{\circ} \mathrm{C}$ and sea surface salinity (SSS) 35.9, and in July 2015 when SST was $15.3^{\circ} \mathrm{C}$ and SSS 35.5 were used. From each sample, single cells were isolated using a micropipette under an IMT2 inverted light microscope (Olympus, Tokyo, Japan) and introduced into wells in a 96-well plate filled with $0.2 \mathrm{~mL}$ of $\mathrm{f} / 2$ medium (Guillard 1975). The plates were incubated at $16^{\circ} \mathrm{C}$ under $80-100 \mu \mathrm{mol}$ photons $\mathrm{m}^{-2} \mathrm{~s}^{-1}$ in a 12:12 light:dark cycle. After some cell divisions, the clonal strains were transferred to plates with progressively increasing well volumes. The strains were maintained in $50 \mathrm{~mL}$ culture flasks and cultivated in the conditions above until they were analyzed.

Morphological features were observed with light (LM) and scanning electron microscopy (SEM). LM observations were first carried out on non-permanent slides using an Olympus IX70 inverted light microscope equipped with differential interference optics and a DP72 digital camera (Olympus, Tokyo, Japan), and using an Olympus BX41 (Olympus, Tokyo, Japan) upright microscope equipped with both differential interference optics, an Osram mercury short arc HBO 100W lamp as light source for epifluorescence, and filtersets U-MWU2 for DAPI (4', 6-diamidino-2-phenylindole) staining (excitation: BP330-385; beamsplitter: DM400; and emission: BA420), and U-MWIB2 for chlorophyll autofluorescence (excitation: BP460-490; beamsplitter: DM505; and emission: BA510IF). This allowed us to visualize the plastids directly, and the nucleus after staining with DAPI. Light micrographs and videos of cells were acquired using a digital camera DP72 (Olympus, 
Tokyo, Japan). One permanent slide was prepared from isolated cells of an environmental sample collected on February 2016 in the Bay of Lampaul, Ouessant Island. These cells were acid-cleaned according to the procedure of Hasle (1978), repeatedly rinsed with Milli-Q water, placed on a coverslip, air-dried and then mounted in Naphrax. For SEM examination, cultivated cells (strain IFR-PDI-01O) were fixed with 1\% acidic Lugol's solution (final concentration), dehydrated and processed according to the method of Chomérat \& Couté (2008) and, for valve details, cells were acid cleaned according to the procedure of Hasle (1978). The samples were concentrated onto $1.2 \mu \mathrm{m}$ pore-size polycarbonate filters followed by rinsing with distilled water. They were then coated with gold and observed using a Quanta 200 (FEI, Eindhoven, The Netherlands) SEM with an acceleration voltage of $10 \mathrm{kV}$ and a secondary electron detector. SEM micrographs are presented on a uniform background using Adobe Photoshop CS5 (V. 12.1, Adobe Systems, San Jose, CA, USA). Cells were measured from LM or SEM digital micrographs using ImageJ software (Rasband 1997-2006). Valve ultrastructure terminology follows Round et al. (1990) and Paddock (1988).

For DNA amplification, single cells of $P$. distortum sp. nov. and Plagiotropis sp. were isolated from field samples or strains by micropipette under an Olympus IX70 inverted light microscope, and deposited on a glass slide. They were observed at 600x magnification, photographed with an Olympus DP72 digital camera, and rinsed with double distilled water (Milli-Q water) before transfer to a $0.2 \mathrm{~mL}$ PCR tube containing $3 \mu \mathrm{L}$ of Milli-Q water. PCR tubes were stored at $-20^{\circ} \mathrm{C}$ until direct PCR amplifications. For PCR, tubes were thawed and processed as described in Nézan et al. (2012). The nuclear marker SSU rDNA was amplified using the primers 18S-FW and 18S-RV (Chomérat et al. 2010).

For phylogenetic analysis, sequences were assembled using BioEdit v. 7.0.9.0 software (Hall 1999) and aligned using MAFFT multiple sequence alignment software version 7 with the selection of the Q-INS-I algorithm, which considers the secondary structure for the alignment (Katoh \& Standley 2013). We aligned relevant sequences downloaded from GenBank with the new sequences generated in our laboratory (Plagiolemma and Plagiotropis). In order to infer the phylogeny of $P$. distortum sp. nov., an alignment matrix was obtained from 49 SSU rDNA sequences (1556 characters). The dataset was analyzed by Maximum Likelihood (ML) [PhyML v. 3.0 (Guindon and Gascuel 2003)] and Bayesian Inference (BI) [Mr Bayes v. 3.1.2 (Ronquist and Huelsenbeck 2003)]. The software jModeltest v. 0.1.1 (Posada 2008) was used to determine the best-suited nucleotide substitution model for the alignment. The General-Time Reversible model $\left(\mathrm{GTR}+\mathrm{I}+\Gamma_{4}\right)$ was chosen, as indicated by the Hierarchical Likelihood Ratio Tests (hLRTs), Akaike Information 
Criterion 1 (AIC1), Akaike Information Criterion 2 (AIC2) and Bayesian Information Criterion (BIC) tests implemented in jModeltest. Bootstrap values (branch support) of trees were obtained after 1000 iterations in ML. For Bayesian inference, four Markov chains were run simultaneously for $2 \times 10^{6}$ generations with sampling every 100 generations. On the $2 \times$ $10^{4}$ trees obtained, the first 2000 were discarded (burn-in) and a consensus tree was constructed from the remaining trees. The posterior probabilities corresponding to the frequency, with which a node is present in preserved trees, were calculated using a coupled Markov Chain Monte Carlo (MCMC) Metropolis-Hastings approach.

\section{Results}

\section{Plagiolemma distortum Nézan sp. nov. (Figs 2-32)}

Diagnosis. Cells with four complexly lobed plastids, $25.7-59.0 \mu \mathrm{m}$ in length. Valves strongly vaulted and narrow in width. Girdle with non-porous bands. Raphe strongly sigmoid. Valves with short transverse median costae (pseudostauros) on each face, slit-like external foramina covered internally by rounded hymenes. 22-25 striae in $10 \mu \mathrm{m}$. Elongated terminal minute holes (micropyles). Internal thickenings around the central pores of the raphe. Elaborate helictoglossae with labia. Cells free or encapsulated.

Morphology. Cells were elliptical with truncated ends in girdle view, lanceolate in valve view displaying different shapes in intermediate views (Figs 2-5, 11-19). Length ranged from 25.7 to $59.0 \mu \mathrm{m}$ for wild cells (mean $36.2 \mu \mathrm{m}$, s.d. $7.3 \mu \mathrm{m} ; n=47$ ) and from 33.6 to $38.3 \mu \mathrm{m}$ for cultured cells from strain IFR-PDI-01O in exponential growth phase (mean $36.2 \mu \mathrm{m}$, s.d. 1.2 $\mu \mathrm{m} ; n=19$ ). The width (transapical axis) was much lower (probably not more than 11-13 $\mu \mathrm{m})$ and could not be measured accurately because cells did not stay in valve view under LM, and tended to collapse when mounted for SEM examinations.

Using LM, each cell contained four yellow-brown plastids and a variable number of refractive granules. The plastids were folded and bilobed, with lobes connected through an isthmus (Figs 2, 8,9). The refractive granules were spherical, without a particular localization. The nucleus was elliptic to round and located in the centre of the cell (Fig.10). Motile cells were observed, single or in pairs, and free or within capsules with trapped sediment particles and a stalk-like structure (Figs 6-7).

Under SEM, the valves were strongly vaulted, with undulating margins (Figs 20, 22 24). The girdle was plain (Figs 21-22). The raphe was strongly sigmoid (Fig. 25). On each 
valve face, one to four transverse median costae (pseudostauros), more or less variable in length, terminated distant from the valve margins (Figs 24-26, 32). In external view, the raphe was borne on a simple angular elevation of the valve (ridge), scarcely interrupted at the central nodule and ending in large openings (Figs 27, 29, 31). Valves displayed slit-like foramina, longitudinally aligned and arranged as transverse striae (Fig. 31), 22-25 in $10 \mu \mathrm{m}$ (mean 24.3, s.d. 0.5; $n=6$ ). Elongated minute holes (micropyles) were present at the apices, arranged in a row at the valve poles between the valve margin and the terminal pore of the raphe (Fig. 29). In internal view, the raphe fissure was interrupted at the central nodule, surrounded by longitudinal crescentic thickenings and ended by elaborate helictoglossae with expanded labia (Figs 28, 30). The inner openings of the valves were rounded without resolved structure (Fig. 32). A video clip of a moving cell is available as supplemental material.

Holotype. SEM-stub (IFR15-A1) with acid cleaned valves of the strain IFR-PDI-01O collected on April 2015 and deposited at the Botanic Garden Meise, Belgium with the accession reference BR-4511 (Figs 24-32). The holotype specimen was illustrated in Fig. 25.

Isotype. Slide of acid-cleaned and rinsed frustules of an environmental sample collected on February 2016 and deposited in the Hustedt Collection, Bremerhaven, Germany (accession number ZU10/96).

Etymology. From Latin 'distortus' which means 'misshapen', with reference to the shape of the cell.

Remarks. The gender of Plagiolemma is neutral (Guiry \& Guiry 2017) and not feminine as considered by Paddock (1988). In consequence, the specific epithet inflata and confusa proposed by Paddock (1988) have an incorrect Latin termination and the endings are therefore here corrected to inflatum and confusum according to the article 32.2 of the International Code of Nomenclature for algae, fungi, and plants (McNeill et al. 2012).

Type locality. Bay of Lampaul, Ouessant Island, Atlantic Ocean $\left(48^{\circ} 27^{\prime} \mathrm{N}, 5^{\circ} 07^{\prime} \mathrm{W}\right)$. Collected by Dr A. Tual.

Habitat and distribution. Plagiolemma distortum was recorded in low numbers in plankton samples from French coasts of the Atlantic Ocean and the English Channel. Cells were 
observed either free or encapsulated. The free-living form was present when water temperature ranged from $8.7^{\circ} \mathrm{C}$ to $17.3^{\circ} \mathrm{C}$, while the encapsulated form was observed when temperature was lower (below $12^{\circ} \mathrm{C}$ ) and light intensity was minimum, corresponding to the winter season.

Molecular phylogenetic data. Four SSU rDNA sequences were generated in our laboratory to infer the phylogenetic position of $P$. distortum. These new sequences were deposited in GenBank with accession numbers from MG587952 to MG587955.

The Maximum Likelihood (ML) phylogenetic tree inferred from the SSU rDNA dataset revealed that sequences of $P$. distortum, together with the clone SGYP684 of an uncultured eukaryote, formed a well-supported group (BS $=100 \%, \mathrm{PP}=1.00)$. This group was sister to Plagiotropis sp. with low support (BS below 65\%, PP below 0.5) while Meuniera membranacea (Cleve) Silva diverged before with high support ( $\mathrm{BS}=97 \%, \mathrm{PP}=1.00)$. The three genera Plagiolemma, Plagiotropis and Meuniera P.C. Silva were part of a poorly supported clade with Pleurosigma W. Smith spp. and Gyrosigma Hassall spp. (BS = 85\%, PP $=0.99)($ Fig. 33).

\section{Discussion}

\section{Morphology.}

Cells of $P$. distortum were elliptical in girdle view like Membraneis challengeri (Grunow) Paddock and Ephemera planamembranacea (Hendey) Paddock but were smaller (Table 1). However, the helictoglossae were elaborate with large labia and were not simple as in $M$. challengeri, and terminal micropyles were present unlike in E. planamembranacea. The raphe was strongly sigmoid as in Donkinia carinata (Donkin) Ralfs but cells were not constricted in the middle. Plagiolemma distortum displayed four plastids per cell, also described for $M$. membranacea and some species of Plagiotropis Pfitzer . But, contrary to the folded, ribbonshaped plastids of $M$. membranacea, the plastids of $P$. distortum were complexly lobed. This particular shape, termed 'butterfly' by Reid (2012), was also encountered in Plagiotropis lepidoptera (Gregory) Kuntze. However, the raphe of $P$. distortum was strongly sigmoid unlike $P$. lepidoptera with a straight raphe. As a result, this new species could only belong to the genus Plagiolemma.

The number and shape of plastids and the raphe were not specified by Paddock (1988) in the description of Plagiolemma species, presumably because he was unable to observe these features. Indeed, he used acid treated samples which had lost the cell contents and he 
did not observe valve views under SEM; he only provided SEM valves in girdle and oblique views (Paddock 1988, pl. 26, figs 3-4).

Morphological comparison of Plagiolemma distortum sp. nov. with other Plagiolemma species.

One of the differences between $P$. distortum sp. nov. and the two other species of Plagiolemma is the number and the length of transverse median costae (pseudostauros) on each valve face. Plagiolemma inflatum Paddock is devoid of such costae, while in $P$. confusum (Hendey) Paddock, each valve face is crossed by a single costa reaching, or nearly reaching, the edge of the valve. In $P$. distortum sp. nov., one to four costae terminate distant from the edge of the valve face. In addition, cell length ranges from 25.7 to $59.0 \mu \mathrm{m}$, between the dimensions given for $P$. confusum $(30-40 \mu \mathrm{m})$ and for P. inflatum (44-98 $\mu \mathrm{m})$. The number of striae in $10 \mu \mathrm{m}$ is $22-25$ in $P$. distortum, from 27 to 30 in $P$. confusum and 26 in $P$. inflatum.

Paddock \& Sims (1981) and Paddock (1988) illustrated a specimen from Tregaron, N. Cornwall (slide Herb. Hendey 7100), which Hendey identified as P. confusum (Paddock \& Sims 1981, pl. 12, fig. 92, Paddock 1988, pl. 27, figs 3-4). However, Paddock (1988) expressed doubt about the identification. Unlike $P$. confusum, with a well-developed transverse median costa (pseudostauros) on each valve face, Hendey's specimen had only a single thin foreshortened costa on one valve face and three or four very short thickenings on the other. As a result, it was more similar to P. distortum, with one to four short costae per valve face. Moreover, its length $(37 \mu \mathrm{m})$ and the number of striae in $10 \mu \mathrm{m}$ (about 25) were close to the average given for $P$. distortum $(36.2 \mu \mathrm{m}$ long and 24.3 striae in $10 \mu \mathrm{m})$. However, SEM micrographs of this specimen were not available to make a detailed comparison with $P$. distortum.

Encapsulated cells were only present in winter, coinciding with minimum light intensity. This is consistent with experiments on epipelic/epilithic diatoms that demonstrated that capsule formation was dependent on at least 'a certain minimum light intensity' and suggested that these capsules might serve as a storage pool of polysaccharides (Hoagland et al 1993, Staats et al. 2000, Leinweber \& Kroth 2015). Indeed, polysaccharides are not secreted by motile benthic diatoms when they are in the dark (Staats et al. 2000). The presence of capsules also coincided with the lowest temperatures $\left(<12^{\circ} \mathrm{C}\right)$ and short days of winter, conditions that favour sexualization, another occasion when capsules are seen for benthic diatoms (Mizuno \& Okuda 1985, Mann 2011, Leinweber \& Kroth 2015). In P. distortum, 
capsules contained one or two moving cells but we were not able to see whether these were in a vegetative or sexual stage.

\section{Habitat and distribution.}

Plagiolemma distortum was found in samples from the upper water column, which could indicate that this species is planktonic. However, it was able to form capsules as previously reported for motile epipelic/epilithic diatoms (Hoagland et al 1993, Staats et al. 2000, Mann 2011, Leinweber \& Kroth 2015). Capsules with trapped sediment particles and a stalk-like structure for attachment to substrata exposed to water motion suggest a benthic habitat (Hoagland et al. 1993). So, the presence of $P$. distortum in plankton samples could be the result of water currents or other physical disruption. The two other described species of the genus Plagiolemma were considered planktonic by previous observers, probably because they had only analyzed plankton samples (Hendey 1964, Simonsen 1974, Paddock 1988). The recent observation of $P$. confusum in sediments strengthens the hypothesis of a benthic habitat for Plagiolemma species (Al-Yamani \& Saburova 2011, pl. 112, figs e-f).

The distribution of $P$. distortum is currently restricted to temperate waters, from French coasts of the Atlantic Ocean and the English Channel, while P. inflatum was reported from the Indian Ocean (Simonsen 1974), and P. confusum was first recorded from West Africa and later from the English Channel, East Africa and Kuwait (Hendey 1964, Foged 1975, Al-Yamani \& Saburova 2011). However, it cannot be excluded that $P$. distortum occurs elsewhere, considering that, in 2014, it appeared at the same period as oceanic dinoflagellates. Hendey (1964) made a similar remark when he considered that $P$. confusum first appeared in the English Channel together with other diatoms usually associated with subtropical waters.

\section{Phylogenetic position of Plagiolemma distortum.}

The phylogenetic analyzes using the SSU rDNA dataset showed that $P$. distortum clustered with clone SGYP684 of an uncultured eukaryote, presumably another species of Plagiolemma found in the Gulf Stream (GenBank accession number KJ763833). This group was sister to Plagiotropis sp. although it was poorly supported. As a result, more sequences are needed to confirm the topology of the tree. The Plagiolemma + Plagiotropis clade with $M$. membranacea in a basal position was sister to the Gyrosigma + Pleurosigma clade, which is congruent with the phylogenetic analysis conducted by Ashworth et al. (2017), using a 3-gene dataset (nuclear-encoded SSU and plastid-encoded $r b c \mathrm{~L}$ and $p s b \mathrm{C}$ ). It was well supported (BS $=97 \%, \mathrm{PP}=1.00$ ) and could correspond to the family Plagiotropidaceae D.G. Mann (Round 
et al. 1990). However, using a cladistic analysis of morphological characters, Reid (2012) concluded that this family could be rejected in favour of the Pleurosigmataceae Mereschkowsky. Nevertheless, Reid's suggestion was not followed by taxonomic registers such as Algaebase (Guiry \& Guiry 2017) and Worms Editorial Board (2017), and our molecular data show that the family Plagiotropidaceae can be conserved.

\section{Emended diagnosis of Plagiolemma.}

Plagiolemma Paddock emend. Nézan

Marine genus with elliptical to circular frustules in girdle view. Transapical axis narrow. Valves delicate, highly vaulted, with or without pseudostauros. Raphe sigmoid in valve view with an inconspicuous central nodule, borne on a ridge, and devoid of fins or fibulae. Plain girdle bands. Helictoglossae large and elaborated, forming a funnel-like structure. Polar endings of outer raphe fissure straight with large openings. Elongated terminal micropyles present. Central area with internal longitudinal crescentic thickenings. Valve with outer slitlike foramina and inner rounded hymenes. Plastids four, complexly lobed. TYPE SPECIES: Plagiolemma inflatum Paddock 1988, p. 73; pl. 26, figs 1-11. OTHER SPECIES:

Plagiolemma confusum (Hendey) Paddock

Plagiolemma distortum Nézan sp. nov.

\section{Conclusions}

Plagiolemma distortum sp. nov. is the third described species within the genus, after $P$. inflatum and P. confusum. Cells were observed free or encapsulated. P. distortum was first reported as co-occurring with oceanic dinoflagellates whilst $P$. confusum was first observed in the English Channel together with other diatoms usually associated with subtropical waters and, the clone SGYP684 was isolated from Gulf Stream waters. Accordingly, further studies should investigate the ecology and phenology of Plagiolemma species.

\section{Acknowledgements}

We are grateful to Marielle Bouildé for providing old literature, Nicolas Gayet for technical assistance in SEM observations, Luc Ector and Zlatko Levkov for their help in the interpretation of the capsules. We would also like to thank observers of the French monitoring network (REPHY) for improving knowledge of the distribution of this new species, and Myriam Rumèbe and Claire Méteigner for collecting the sample used for obtaining 
Plagiotropis sequences. The comments and suggestions of two anonymous reviewers and the editors of Diatom Research greatly improved this work.

\section{Disclosure statement}

No potential conflict of interest was reported by the authors.

\section{Supplemental data}

Supplemental data for this article can be accessed

http://dx.doi.org/10.1080/0269249X.2018.1468359

\section{References}

AL-YAMANi F.Y. \& SABUROVA M.A. 2011. Illustrated guide on the benthic diatoms of Kuwait's marine environment. Kuwait Institute for Scientific Research, Safat. 358 pp. ANDERSEN P. \& THRONDSEN J. 2003. Estimating cell numbers. In: Manual on harmful marine microalgae (Ed by G.M. HALLEgRAefF, D.M. ANDERson \& A.D. CEMBella), pp. 99129. UNESCO, Paris.

Ashworth M.P., Lobban C.S., Witkowski A., Theriot E.C., SAbiR M.J., BAeshen M.N., HAJARAH N.H., BAESHEN N.A., SABIR J.S. \& JANSEN R.K. 2017. Molecular and morphological investigations of the stauros-bearing, raphid pennate diatoms (Bacillariophyceae): Craspedostauros E.J.Cox, and Staurotropis T.B.B. Paddock, and their relationship to the rest of the Mastogloiales. Protist 168: 48-70.

Chomérat N. \& Couté A. 2008. Protoperidinium bolmonense sp. nov. (Peridiniales, Dinophyceae), a small dinoflagellate from a brackish hypereutrophic lagoon (South of France). Phycologia 47: 392-403.

Chomérat N., Sellos D.Y., Zentz F. \& NéZAn E. 2010. Morphology and molecular phylogeny of Prorocentrum consutum sp. nov. (Dinophyceae), a new benthic dinoflagellate from South Brittany (Northwestern France). Journal of Phycology 46: 183-194. 
Cox E.J. \& WiLliams D.M. 2000. Systematics of naviculoid diatoms: the interrelationship of some taxa with a stauros. European Journal of Phycology 35: 273-282.

FogED F. 1975. Some littoral diatoms from the coast of Tanzania. Bibliotheca Phycologia 16: $1-127$.

GUILLARD R.L.L. 1975. Culture of phytoplankton for feeding marine invertebrates. In:

Culture of Marine Invertebrates Animals (Ed by W.L. SMITH \& M.H. CHANLEY), pp. 29-60. Plenum Press, New York.

GUINDON S. \& GASCUEL O. 2003. A simple, fast, and accurate algorithm to estimate large phylogenies by maximum likelihood. Systematic Biology 52: 696-704.

GUIRY M.D. \& GUIRY G.M. 2017. Algaebase. World-wide electronic publication. National University of Ireland, Galway. Available from: http://www.algaebase.org [Accessed 29 June 2017].

HALL T.A. 1999. BioEdit: a user-friendly biological sequence alignment editor and analysis program for Windows 95/98/NT. Nucleic Acids Symposium Series 41: 95-98.

HASLE G.R. 1978. Diatoms. In: Phytoplankton manual (Ed by A. Sournia), pp. 136-142. UNESCO, Paris.

HASLE G.R. \& SYVERTSEN E.E. 1996. Marine diatoms. In: Identifying marine phytoplankton (Ed by C.R. TomAs), pp.5-385. Academic Press, San Diego.

HENDEY N.I. 1964. Bacillariophyceae (Diatoms), Part V. In: An introductory account of the smaller algae of British coastal waters. Fisheries Investigations. Series IV, Her Majesty’s Stationery Office, London, 317 pp., 45 pls.

Hoagland K.D., Rosowski J.R., GRetz M.R. \& RoEMER S.C. 1993. Diatom extracellular polymeric substances: function, fine structure, chemistry, and physiology. Journal of Phycology 29: 537-566. 
KATOH K.\& STANDLEY D.M. 2013. MAFFT multiple sequence alignment software version 7: improvements in performance and usability. Molecular Biology and Evolution 30: $772-780$.

LeINWEBER K. \& KROTH P.G. 2015. Capsules of the diatom Achnanthidium minutissimum arise from fibrillar precursors and foster attachment of bacteria. PeerJ 3: e858.

Mann D.G. 2011. Size and sex. In: The diatom world. Series “Cellular Origin, Life in Extreme Habitats and Astrobiology 19” (Ed by J. SECKBACH \& J.P. KOCIOLEK), pp.145-166. Springer, Dordrecht.

McNeill J., Barrie F.R., Buck W.R., Demoulin V., Greuter W., Hawksworth D.L., Herendeen P.S., Knapp S., Marhold K., Prado J., Prud’homme van Reine W.F., SMith G.F., WIERSEMA J.H. \& TURLAND N.J. 2012. International Code of Nomenclature for algae, fungi, and plants (Melbourne Code). Regnum Vegetabile, Vol.154. Koeltz Scientific Books, Königstein. 208 pp.

MizunO M. \& OKUDA K. 1985. Seasonal change in the distribution of cell size of Cocconeis scutellum var. ornata (Bacillariophyceae) in relation to growth and sexual reproduction. Journal of Phycology 21: 547-553.

Nézan E., Tillmann U., Bilien G., Boulben S., Chèze K., Zentz F., Salas R. \& CHOMÉRAT N. 2012. Taxonomic revision of the dinoflagellate Amphidoma caudata: transfer to the genus Azadinium (Dinophyceae) and proposal of two varieties, based on morphological and molecular phylogenetic analyses. Journal of Phycology 48: 925939.

PADDOCK T.B.B. 1988. Plagiotropis Pfitzer and Tropidoneis Cleve, a summary account. Bibliotheca Diatomologica 16: 1-152 + 38 pls.

PADDOCK T.B.B. \& SiMS P.A. 1981. A morphological study of keels of various raphe-bearing diatoms. Bacillaria 4: 177-222. 
PosadA D., 2008. jModelTest: Phylogenetic model averaging. Molecular Biology and Evolution 25: 1253-1256.

RASBAND W.S. 1997-2006. ImageJ. 1.37c. (Ed. By National Institutes of Health), Bethesda, Maryland.

REID G. 2012. A revision of the family Pleurosigmataceae (Bacillariophyta). Diatom Monographs 14: 1-163.

RONQUIST F.\& HUELSENBECK J.P. 2003. MrBayes 3: Bayesian phylogenetic inference under mixed models. Bioinformatics 19: 1572-1574.

Round F.E., CRAWFord R.M. \& MANN D.G. 1990. The diatoms. Biology and morphology of the genera. Cambridge University Press, Cambridge. 747 pp.

SIMONSEN R. 1974. The diatom plankton in the Indian Ocean Expedition of R/V "Meteor" 1964-1965. “Meteor” Forschung-Ergebnisse Reihe D 19: 1-107.

StaAts N., Stal L.J., De Winder B. \& Mur L.R. 2000. Oxygenic photosynthesis as driving process in exopolysaccharide production of benthic diatoms. Marine Ecology Progress Series 193: 261-269.

StePAneK J.G. \& KociOLeK J.P. 2014. Molecular phylogeny of Amphora sensu lato (Bacillariophyta): an investigation into the monophyly and classification of the Amphoroid diatoms. Protist 165: 177-195.

StePANeK J.G. \& KociOLEK J.P. 2016. Re-examination of Mereschkowsky’s genus Tetramphora (Bacillariophyta) and its separation from Amphora. Diatom Research 31: $123-148$.

Worms EdITORIAL BOARD. 2017. World Register of Marine Species. Available from: http://www.marinespecies.org [Accessed 29 June 2017]. 
Table 1. Morphological comparisons between the new species, P. distortum, and some related raphid species.

\begin{tabular}{|c|c|c|c|c|c|c|c|c|}
\hline Features & $\begin{array}{l}\text { Plagiolemma } \\
\text { distortum sp. nov. }\end{array}$ & $\begin{array}{l}\text { Plagiolemma } \\
\text { confusum }\end{array}$ & $\begin{array}{l}\text { Plagiolemma } \\
\text { inflatum }\end{array}$ & $\begin{array}{l}\text { Membraneis } \\
\text { challengeri }\end{array}$ & $\begin{array}{l}\text { Ephemera } \\
\text { planamembranacea }\end{array}$ & Donkinia carinata & $\begin{array}{l}\text { Plagiotropis } \\
\text { lepidoptera }\end{array}$ & $\begin{array}{l}\text { Meuniera } \\
\text { membranacea }\end{array}$ \\
\hline $\begin{array}{l}\text { Cell shape (girdle } \\
\text { view) }\end{array}$ & Elliptical & Circular & n.a. & Elliptical & Elliptical & $\begin{array}{l}\text { Rectangular, } \\
\text { constricted in the } \\
\text { center }\end{array}$ & $\begin{array}{l}\text { Rectangular, } \\
\text { constricted in the } \\
\text { center }\end{array}$ & Rectangular \\
\hline Plastids per cell & 4 & n.a. & n.a. & n.a. & Numerous & 2 & $2(4)$ & 4 \\
\hline Plastids shape & Complexly lobed & n.a. & n.a. & n.a. & Cocciform & $\begin{array}{l}\text { Ribbon-shaped and } \\
\text { folded }\end{array}$ & Complexly lobed & $\begin{array}{l}\text { Ribbon-shaped and } \\
\text { folded }\end{array}$ \\
\hline Apical axis $(\mu \mathrm{m})$ & $25.7-59.0$ & $38-40$ & $44-98$ & $85-270$ & $66-90$ & $115-140$ & $59-200$ & $50-90$ \\
\hline $\begin{array}{l}\text { Transapical axis } \\
(\mu \mathrm{m})\end{array}$ & $11-13$ & $6-8$ & n.a. & n.a. & $15-30$ & $18-20$ & $21-47$ & $30-40$ \\
\hline Striae in $10 \mu \mathrm{m}$ & $22-25$ & $27-30$ & 26 & $18-24$ & $28-30$ & 20 & $18-22$ & 40 \\
\hline Girdle bands & Plain & Plain & Plain & Plain & Plain & Plain & Plain & Finely porous \\
\hline Raphe shape & Strongly sigmoid & n.a. & n.a & n.a & Straight with fins & Strongly sigmoid & Straight & Straight with fins \\
\hline $\begin{array}{l}\text { External polar raphe } \\
\text { endings }\end{array}$ & $\begin{array}{l}\text { Straight, expanded in } \\
\text { a pore }\end{array}$ & n.a. & n.a & $\begin{array}{l}\text { Straight, expanded in } \\
\text { a pore }\end{array}$ & $\begin{array}{l}\text { Straight, expanded in } \\
\text { a pore }\end{array}$ & $\begin{array}{l}\text { Deflected, expanded } \\
\text { in a pore }\end{array}$ & $\begin{array}{l}\text { Curved and slightly } \\
\text { expanded }\end{array}$ & $\begin{array}{l}\text { Straight, expanded in } \\
\text { a pore }\end{array}$ \\
\hline $\begin{array}{l}\text { Valve shape (girdle } \\
\text { view) }\end{array}$ & Strongly vaulted & Strongly vaulted & Strongly vaulted & Strongly vaulted & Strongly vaulted & Flat & Flat & Flat \\
\hline $\begin{array}{l}\text { Valve shape (valve } \\
\text { view) }\end{array}$ & Lanceolate & Linear-lanceolate & n.a. & n.a. & n.a. & Linear-lanceolate & Linear-lanceolate & $\begin{array}{l}\text { Elliptical with } \\
\text { pointed ends }\end{array}$ \\
\hline Foramina shape & Slit-like & n.a. & Slit-like & Slit-like & Slit-like & Slit-like & Slit-like & $\begin{array}{l}\text { Round, occluded by } \\
\text { perforated vela }\end{array}$ \\
\hline $\begin{array}{l}\text { Hymenes } \\
\text { shape }\end{array}$ & Rounded, occluded & n.a. & Rounded, occluded & n.a. & n.a. & Oval, occluded & n.a. & n.a. \\
\hline $\begin{array}{l}\text { Pseudostauros costae } \\
\text { per valve face }\end{array}$ & 1 to 4 , short & 1 , long & Absent & $\begin{array}{l}\text { Variable in number } \\
\text { and length }\end{array}$ & 4 , long & Absent & Absent & 1 , long \\
\hline
\end{tabular}




\begin{tabular}{|c|c|c|c|c|c|c|c|c|}
\hline Helictoglossae & Elaborate & n.a. & n.a. & Simple & n.a. & Simple & Elaborate & n.a. \\
\hline Micropyles & Present & n.a. & Present & Absent & Absent & Present & Present & n.a. \\
\hline References & This study & $\begin{array}{l}\text { Hendey (1964), } \\
\text { Paddock (1988) }\end{array}$ & Paddock (1988) & $\begin{array}{l}\text { Paddock (1988), } \\
\text { Hasle \& Syvertsen } \\
\text { (1996) }\end{array}$ & $\begin{array}{l}\text { Paddock (1988), } \\
\text { Hasle \& Syvertsen } \\
\text { (1996) }\end{array}$ & $\begin{array}{l}\text { Round et al. (1990), } \\
\text { Al-Yamani \& } \\
\text { Saburova (2011) }\end{array}$ & $\begin{array}{l}\text { Paddock (1988), } \\
\text { Round et al. (1990), } \\
\text { Al-Yamani \& } \\
\text { Saburova (2011) }\end{array}$ & $\begin{array}{l}\text { Round et al. (1990), } \\
\text { Hasle \& Syvertsen } \\
\text { (1996), Cox \& } \\
\text { Williams (2000) }\end{array}$ \\
\hline
\end{tabular}

Notes: Taxon position in the table indicates degree of similarity to $P$. distortum. n.a.: not available. 


\section{Figures}

Fig. 1. Distribution of Plagiolemma distortum sp. nov. (dashed line) and the sampling stations around Brittany, France (filled circles for ordinary localities and an open circle for type locality).

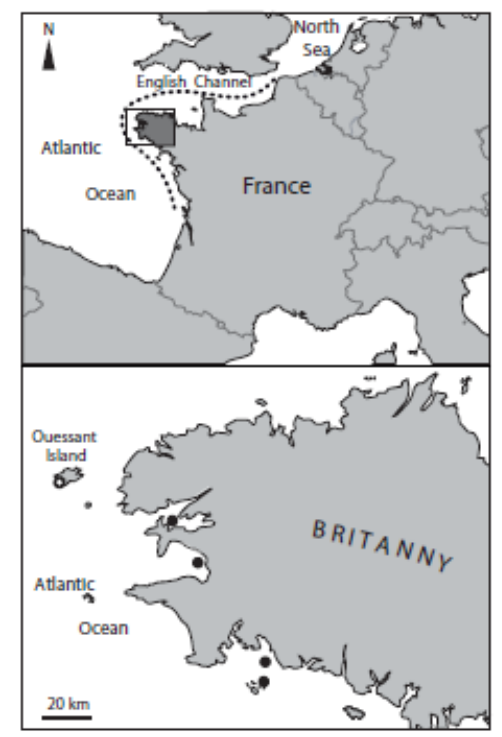


Figs 2-10. Light and epifluorescence micrographs of Plagiolemma distortum sp. nov. Fig. 2. Median focus of a cell in girdle view, showing plastids, nucleus and granules. Fig. 3. Cell in oblique girdle view. Fig. 4. Cell in oblique polar view. Fig. 5. Cell in oblique valve view. Fig. 6. Capsule with two cells inside and a stalk-like structure (arrowhead). Fig. 7. Surface focus of a capsule with trapped sediment particles. Fig. 8. Cell showing the yellow-brown color of the plastids. Fig. 9. The same cell in epifluorescence microscopy showing the complexly lobed plastids (red). Fig. 10. DAPI-stained cells showing the autofluorescent nucleus (blue). Scale bars $=10 \mu \mathrm{m}$.

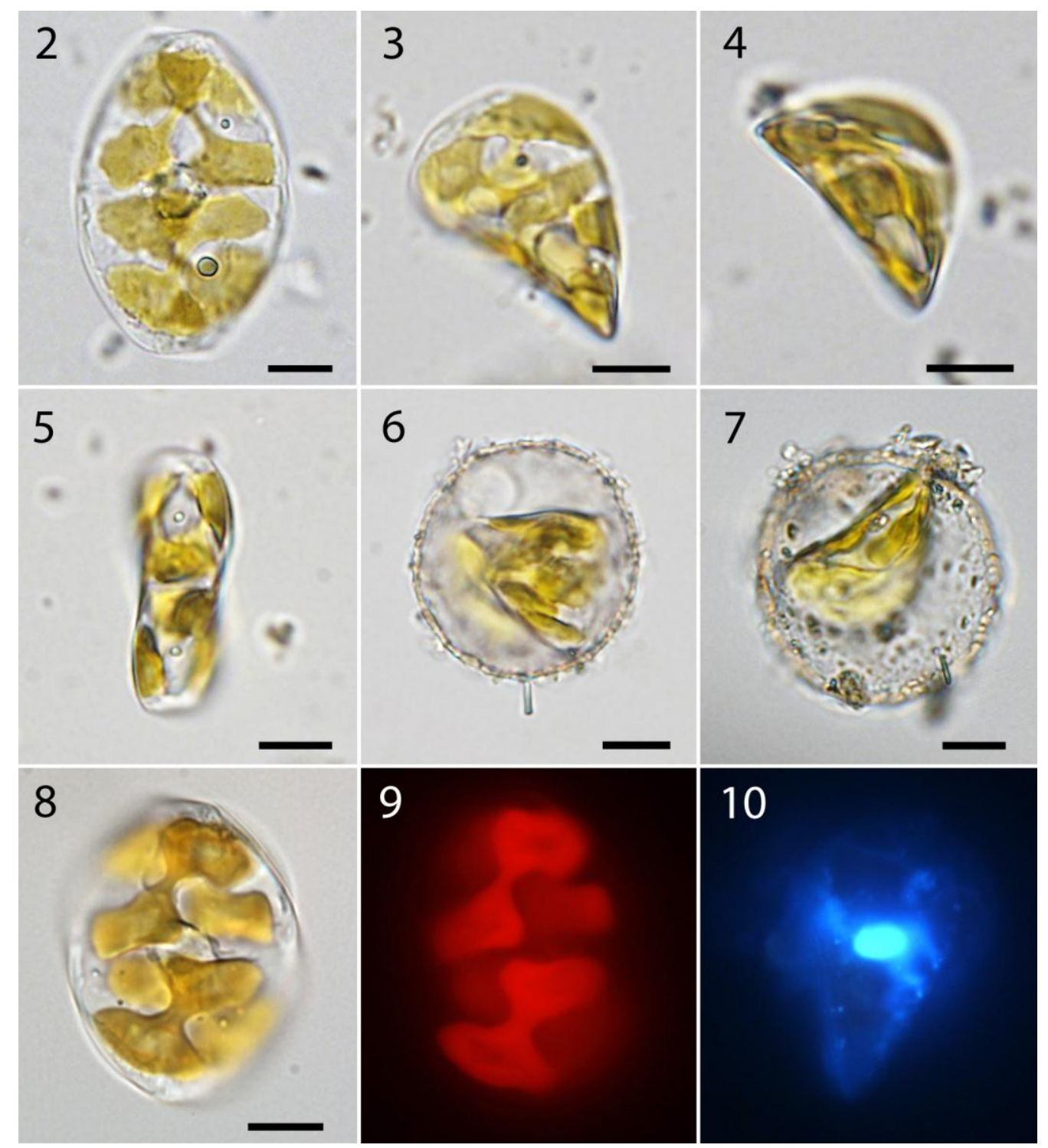


Figs 11-19. LM micrographs of a frustule of Plagiolemma distortum sp. nov. Fig. 11. Girdle view. Fig. 12. Oblique girdle view. Fig. 13. Oblique polar view. Figs 14-19. Surface focus of valve faces in different views. Figs 14-16. The face of the first valve. Figs 17-19. The face of the second valve. Scale bar $=10 \mu \mathrm{m}$.

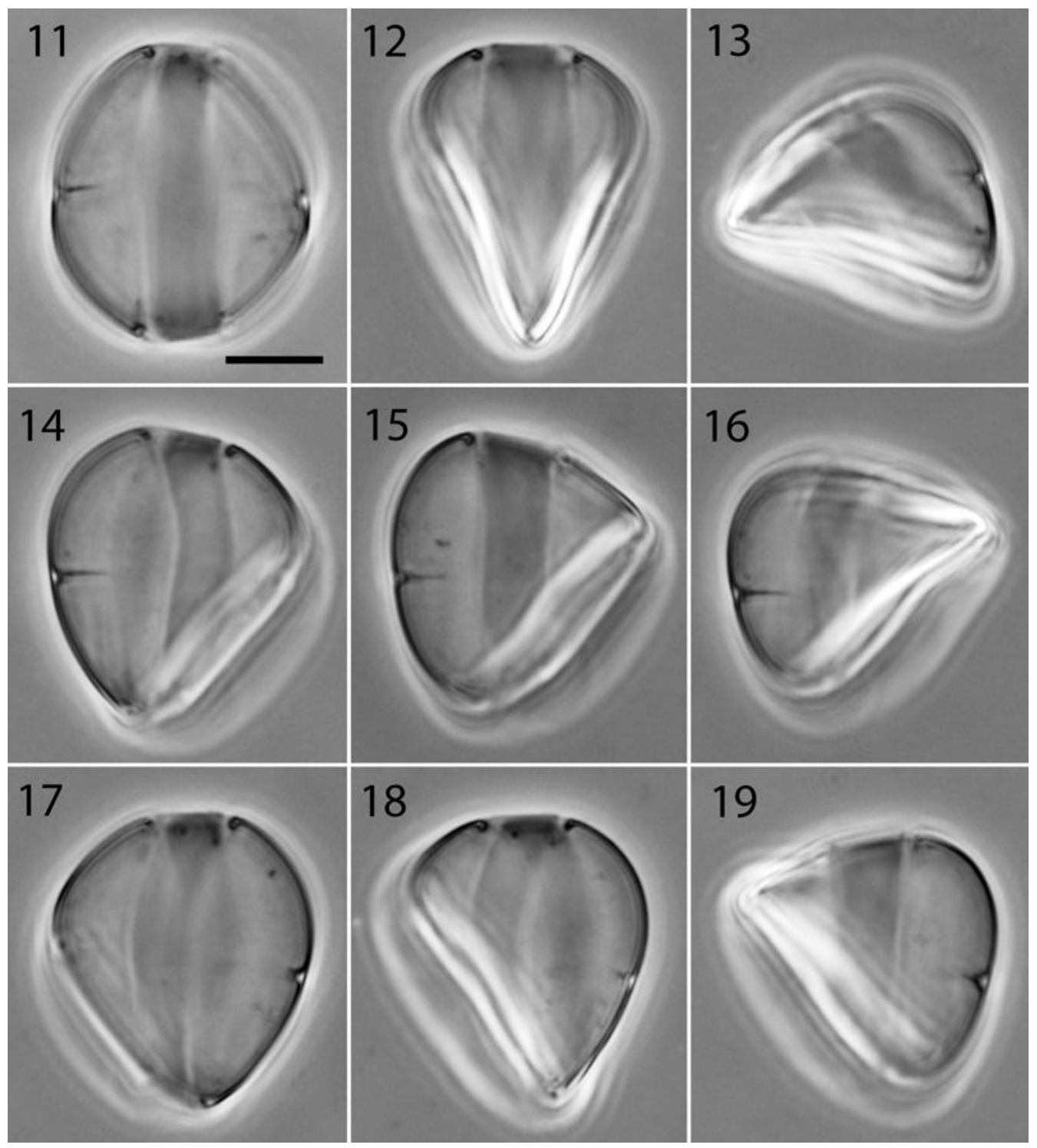


Figs 20-26. SEM micrographs of Plagiolemma distortum sp. nov. (strain IFR-PDI-01O). Fig. 20. Frustule in girdle view. Fig. 21. The same frustule in oblique girdle view. Fig. 22. Frustule in oblique polar view. Fig. 23. Frustule in oblique valve view. Fig. 24. Two valves in girdle view. Note the undulating margins. Fig. 25. Valve in valve view. Note the sigmoid raphe. Fig. 26. Valve interior view. $(\mathrm{g}=$ hyaline girdle; $\mathrm{h}=$ helictoglossa; $\mathrm{ps}=$ pseudostauros (transverse median costa); $r=$ raphe; $v=$ valve). Fig. 25. Holotype specimen. Scale bars $=10 \mu \mathrm{m}$.

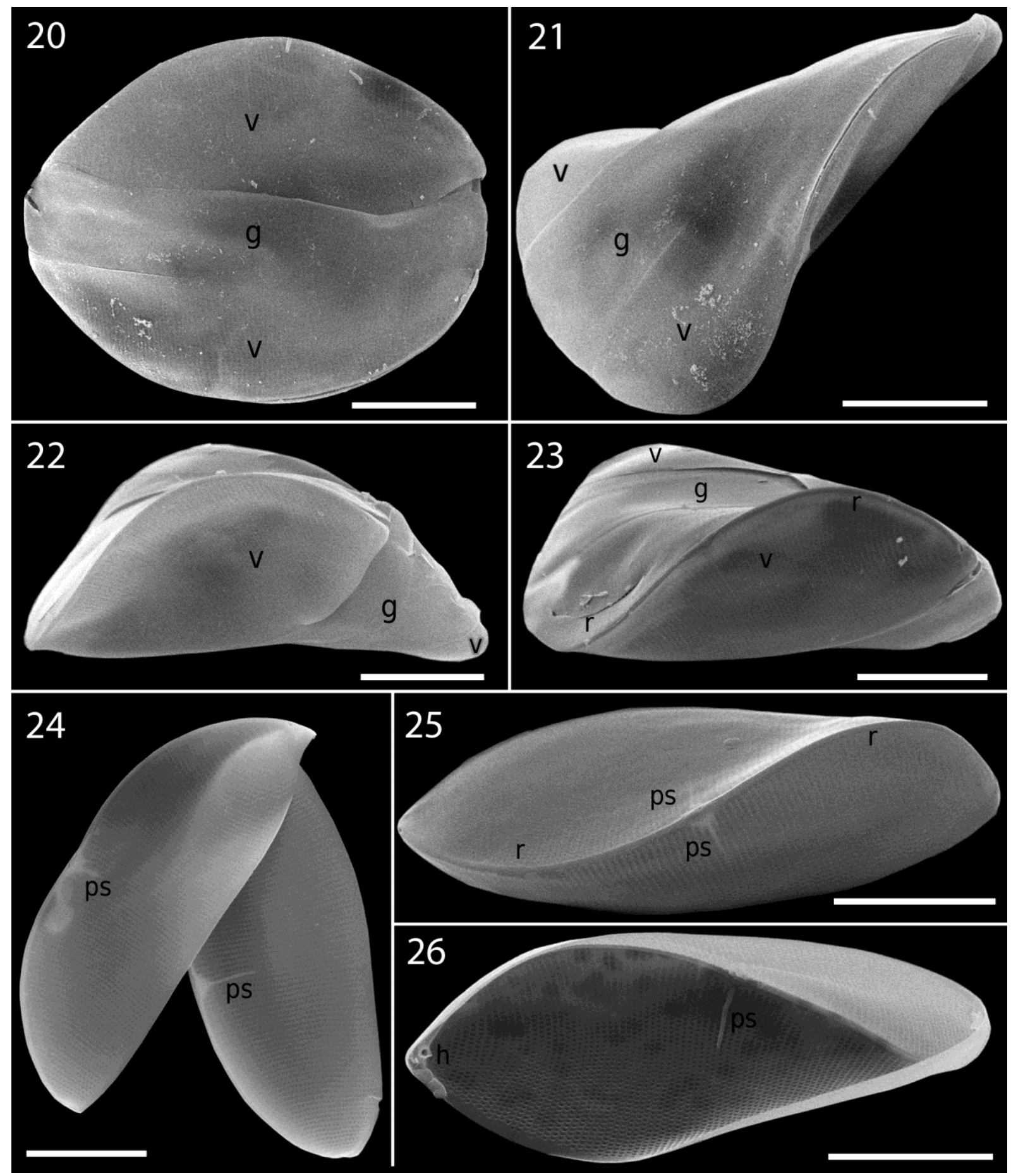


Figs 27-32. SEM micrographs of Plagiolemma distortum sp. nov. (strain IFR-PDI-01O). Figs 27, 29, 31. External details. Figs 28, 30, 32. Internal details. Fig. 27. Valve outer surface at the central nodule. Note raphe borne on a ridge with closely spaced central endings. Fig. 28 . Valve inner surface at central nodule. Note raphe endings (arrowheads) and longitudinal crescentic thickenings (asterisks). Fig. 29. Valve polar exterior in valve view with the terminal pore (arrowhead) of the raphe and the row of elongated micropyles. Fig. 30. Valve polar interior with the elaborate helictoglossa at the raphe ending. Fig. 31. Valve polar exterior in girdle view with transverse striae, a terminal raphe pore (arrowhead) and elongated micropyles. Fig. 32. Inner rounded hymenes and pseudostauros. $(\mathrm{h}=$ helictoglossa; $\mathrm{m}=$ row of micropyles, $\mathrm{ps}=$ pseudostauros (transverse median costa); $\mathrm{r}=$ raphe). Scale bars $=1 \mu \mathrm{m}$.

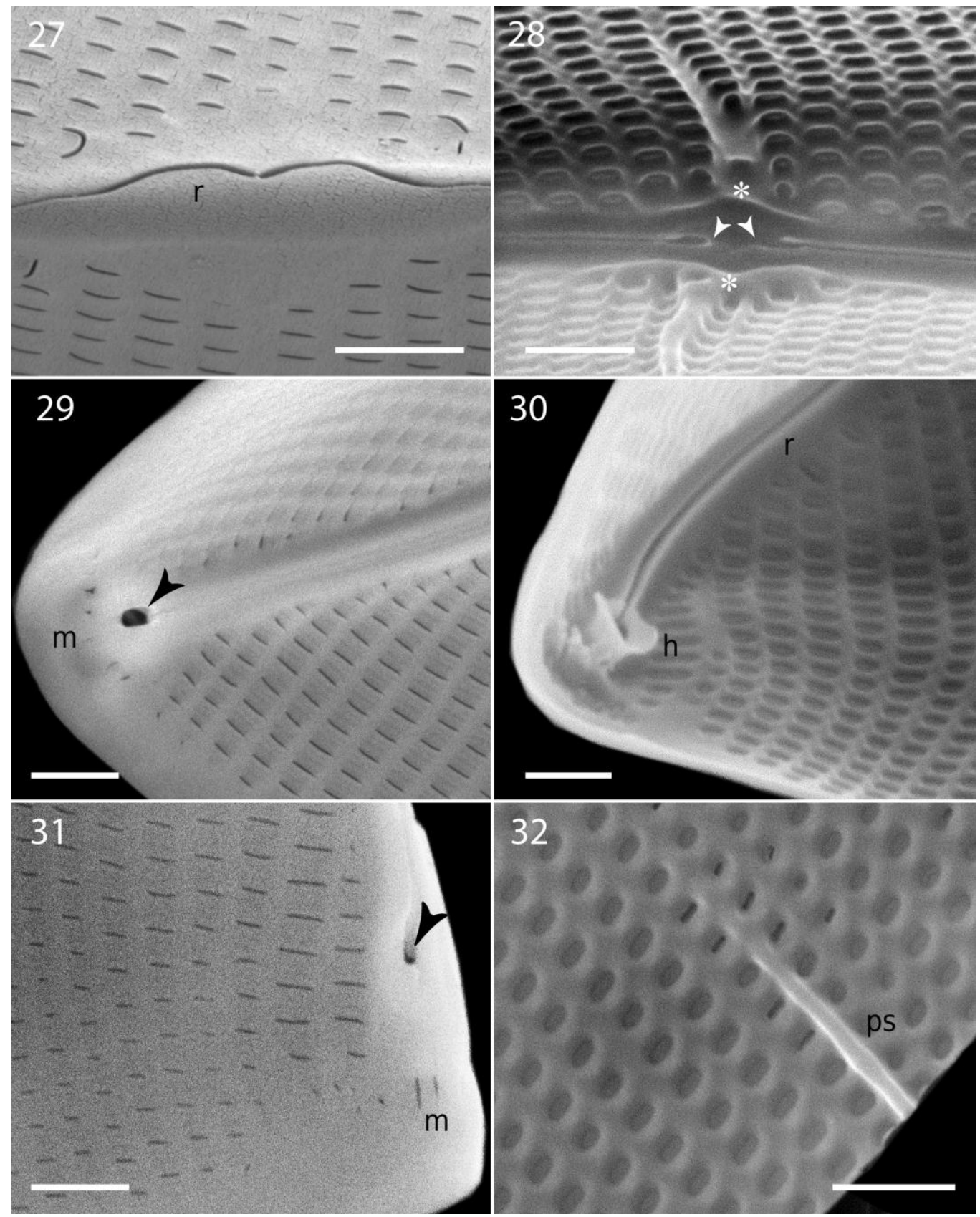


Fig. 33. Maximum likelihood phylogeny inferred from a SSU rDNA data matrix (49 sequences and 1556 characters). The tree was rooted using Fragilaria as outgroup. The General-Time Reversible model $\left(\mathrm{GTR}+\mathrm{I}+\Gamma_{4}\right)$ was chosen in jModeltest. Filled circles indicate bootstrap values of 100 for Maximum Likehood (ML) and posterior probabilities of 1.00 for Bayesian Inference (BI). ML bootstrap values and BI posterior probabilities are shown near each node. If bootstrap values were $<65$ and posterior probabilities $<0.5$, the symbol ' + ' was used. This ('-') indicates lack of resolution in the Bayesian analysis. Newly acquired sequences are shown in bold. Scale bar = nucleotide substitutions per site.

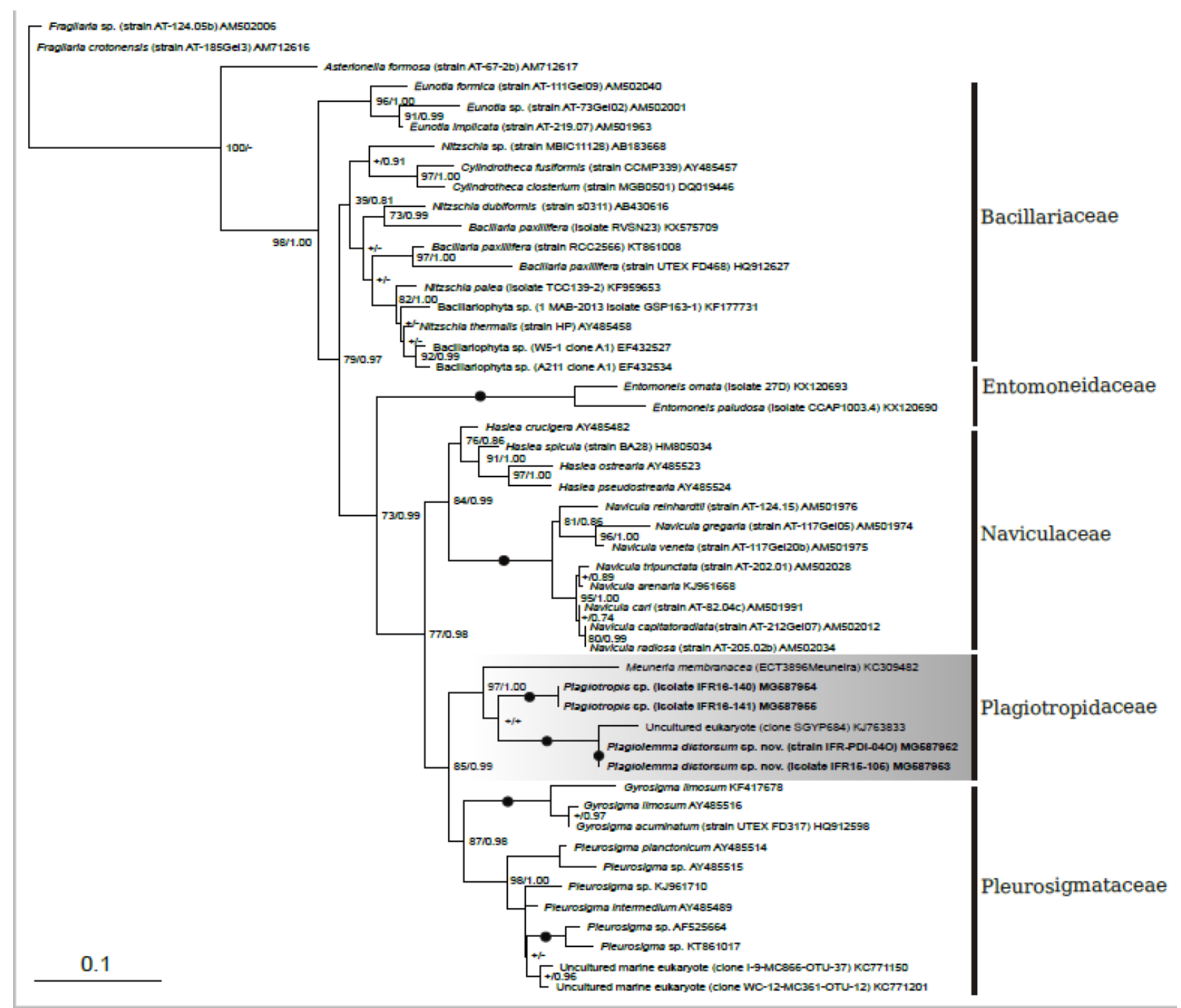

Supplementary information. Video Clip S1. A moving cell of Plagiolemma distortum sp. nov. 